Board of Governors of the Federal Reserve System

\author{
International Finance Discussion Papers
}

Number 558

July 1996

\title{
STOCKHOLDING BEHAVIOR OF U.S. HOUSEHOLDS: EVIDENCE FROM THE 1983-89 SURVEY OF CONSUMER FINANCES
}

Carol C. Bertaut

NOTE: International Finance Discussion Papers are preliminary materiais circuiated to stimulate discussion and critical comment. References in publications to International Finance Discussion Papers (other than an acknowledgement that the writer has had access to unpublished material) should be cleared with the author or authors. 


\begin{abstract}
Most households persistently invest in riskless assets but not stocks, and may do so because they perceive the information required for market participation to be costly relative to expected benefits. In a CCAPM, increased risk aversion, income risk, and lower resources reduce the information expense sufficient to deter stockholding. Bivariate probit analysis using the 1983-89 Survey of Consumer Finances shows that households with lower risk aversion, higher education, and greater wealth who were nonstockholders in 1983 had an increased conditional probability of entering by 1989, while 1983 stockholders with lower resources, more limited education, and greater risk aversion were more likely to be nonstockholders by 1989 .
\end{abstract}




\title{
STOCKHOLDING BEHAVIOR OF U.S. HOUSEHOLDS: EVIDENCE FROM THE 1983-89 SURVEY OF CONSUMER FINANCES
}

\author{
Carol C. Bertaut ${ }^{1}$
}

\section{Introduction}

Financial advisors stress the importance of investing part of the household portfolio in stocks to provide adequate resources for retirement, as well as to meet rising costs of a college education, and to provide for the possibility of nursing home or other long-term care for household members or elderly parents. Typical investment profiles for young, middle aged, and older households recommend at least some investment in stocks, with the proportion of the portfolio in stocks highest for young households who have the longest investment horizons. However, despite a historic excess return on stocks over short-term riskless assets of over 600 basis points ${ }^{1}$, most U.S. households do not invest in the stock market. Only 20 percent of U.S. households held publicly traded stocks or shares of mutual stock funds in 1983, according to the Survey of Consumer Finances. Despite the growth of mutual stock funds, this percentage was about unchanged in 1989 , and had only increased to about 28 percent in 1992. Adding stocks held indirectly in IRAs, 401Ks, and defined benefit pensions increases the stock ownership to 38 percent of the population in 1992 . While many nonstockholders have few financial assets at all, the puzzle of nonstockholders is by no means restricted to low-wealth households. In 1992, 45 percent of households with holdings of

The author is an Economist in the Division of International Finance, Board of Governors of the Federal Reserve System. I am grateful for many helpful comments and suggestions from Michael Haliassos and Martha Starr-McCluer, and I also gratefully acknowledge comments and suggestions on an earlier version of this paper from Martin Baily, Allan Drazen, William Evans, John Haltiwanger, and Andrew Lyon. Matthew Field provided excellent research assistance. This paper represents the views of the author and should not be interpreted as reflecting those of the Board of Governors of the Federal Reserve System or other members of its staff. 
liquid riskless assets between $\$ 60,000$ and $\$ 100,000$ did not directly hold shares of stocks or mutual stock funds, and 28 percent of households with over $\$ 100,000$ in liquid riskless assets did not hold stocks directly. ${ }^{2}$

That most households hold incomplete portfolios has been recognized in empirical papers based on the original Surveys of Financial Characteristics of Consumers conducted in the early 1960s. Most of these papers motivated incomplete portfolios by assuming differential "monitoring costs" for some assets, or by assuming that short sales restrictions prevent individuals from optimally holding negative positions in some assets. The precise reasons for why households do not hold stocks are relevant for a wide range of papers estimating portfolio shares. Uhler and Cragg (1971) investigated portfolio diversification using the 1960s Surveys, assuming that there exist "nuisance costs" to holding small quantities of some assets, which decrease with the amount held. King and Leape (1984) use the 1979 Survey of Consumer Financial Decisions while Perraudin and Sorensen (1991) use the 1983 Survey of Consumer Finances to study the determinants of not holding certain assets in a particular year, and then estimate asset demands. Agell and Edin (1990) perform a similar exercise using data on Swedish households. ${ }^{3}$ King and Leape (1987) attribute the limited incidence of stockholding to the exogenous and random arrival of information over time, implying that age should contribute to the probability of being a stockholder. Ioannides (1992) studies the effects of changes in variables relating to the life cycle on portfolio shares. Haliassos and Bertaut (1995) explore theoretical reasons why individual households abstain from stock market participation. Using data for the 1983 Survey of Consumer Finances, they find econometric support for the hypothesis that actual or perceived costly information about the stock market can account for agents who hold portfolios of riskless assets but not stocks.

This paper estimates a bivariate probit model using the most recent panel data from the 1983 and 1989 Surveys of Consumer Finances and focuses specifically on the decision of 
whether to hold stocks. By looking at households six years apart, it can assess how household characteristics and major life changes affect portfolio allocation. If costly information about the stock market can deter households from participation, then household portfolios are likely to display persistent behavior, and the probability of consistently being a stockholder or a nonstockholder should exceed the probability of changing stockholder status. Conditional on being a nonstockholder in 1983 , the probability of becoming a stockholder by 1989 should be larger for households with greater ability to process financial information or to hire financial advisors. If costs of monitoring the portfolio recur each year, a lower level of education or lower wealth should contribute to the decision to leave the stock market in 1989, after having held stocks in 1983. The standard CCAPM and the role of information or

monitoring costs in deterring stock market participation are presented in Section 2 . Section 3 presents an econometric model for investigating stock market participation among U.S. households. Details of the data set are presented in Section 4. Section 5 presents results from the bivariate probit estimation, and section 6 concludes.

\section{The Stockholding Puzzle and Information Costs in a Basic \\ Consumption Capital Asset Pricing Model}

In the basic Consumption CAPM, each agent maximizes expected utility. The utility function is additively separable, and future utility is discounted at the rate $\beta$. The agent can borrow or invest in two assets, one with a riskless rate of return and one with stochastic return (stocks). The agent's optimization problem is:

$$
\operatorname{Max} E \sum_{t=0}^{T} \beta^{\prime} U\left(c_{t}\right)
$$

subject to the constraints 


$$
\begin{gathered}
c_{t}=A_{t}+y_{t}-s_{t} \\
A_{t+1}=s_{t}(1+r)+\alpha_{t} z_{t}
\end{gathered}
$$

where: $c_{t}$ is real consumption in time $t, y_{t}$ is exogenous real labor income in $t, A_{t}$ is total wealth at time $t, s_{t}$ is total real saving in $t, \alpha_{t}$ is the amount saved in the risky asset in time $t$, $1+r$ is the gross riskless return, and $z_{t}$ is the excess return on stocks over the riskless rate. The Bellman equation for the problem becomes:

$$
V_{1}\left(A_{t}\right)={ }_{c_{1}, \alpha_{t}}^{\operatorname{Max}}\left\{U\left(c_{t}\right)+\beta E\left[V_{t+1}\left(A_{t+1} \mid t\right]\right\}\right.
$$

Imposing the constraints and solving for the optimal choices of total saving $\mathbf{s}$ and risky assets $\alpha$ generates the first order conditions for time t:

$$
\begin{gathered}
U^{\prime}\left(c_{t}\right)=\beta(1+r) E_{t} U^{\prime}\left(c_{t+1}\right) \\
\beta E_{t}\left[U^{\prime}\left(c_{t+1}\right) z_{t}\right]=0
\end{gathered}
$$

The stockholding puzzle arises from FOC (4), which cannot be satisfied by holding zero risky assets in both periods $t$ and $t+1$ when $z_{t}$, the expected equity premium, is positive.

If we introduce a "cost" of stock market participation, representing either the lumpsum expense of obtaining information by purchasing investment guides or subscribing to investment magazines, or the opportunity cost of the time spent in obtaining investment information, ${ }^{4}$ the constraints become: 


$$
\begin{gathered}
c_{i}=A_{i}+y_{i}-I-s_{i} \\
A_{t+1}=s_{t}(1+r)+\alpha_{t} z_{t}
\end{gathered}
$$

if the household makes the necessary expense $I$ and invests in stocks, or

$$
\begin{aligned}
& c_{t}=A_{t}+y_{t}-s_{t} \\
& A_{t+1}=s_{t}(1+r)
\end{aligned}
$$

if the household does not acquire the information and invests in riskless assets only. If the cost of acquiring the information necessary for market participation is perceived to be sufficiently high to remove the expected utility gain, the household will not make the expenditure. If costs are not just "ticket fees" that permit participation, but some fraction also recurs each period as the expense of monitoring of the portfolio and learning of new investment opportunities, they may be sufficient to make an individual persistently abstain from the market.

Simulations of a calibrated life-cycle model allow investigation of how this "cost" varies by degree of risk aversion, with the introduction of labor income risk, and with the introduction of a bequest motive. The income process used is described in detail in Bertaut and Haliassos (1996). Households are assumed to live for three 20-year periods, and to receive exogenous labor income in each period. Incomes are calibrated from the average income of households with the same age and level of education in the 1992 Survey of Consumer Finances, distinguishing between those without a high school diploma or equivalency degree, those with a high school diploma but no college degree, and those with a college degree or more. This classification is motivated by similarities of long-run income processes of such households (see Hubbard et. al., 1994, 1995). When income risk is 
introduced, households face transitory and permanent income shocks which also vary by education level, following the process defined in Hubbard et. al. The riskless return is set to the mean riskless rate estimated by Siegel (1992) over the period 1800-1990, which is similar to the Mehra-Prescott riskless return. Stock returns can take a high or low value with equal probability, matching the first two moments of the Mehra-Prescott long-run empirical distribution. The expected value and standard deviation of 20 -year holding returns are derived following the process described in Haliassos and Lyon (1994).

Households are assumed to have CRRA utility functions with (constant) degree of relative risk aversion $\gamma$. A bequest motive is introduced by allowing for a bequest $\mathrm{G}$ in the third period:

$$
U\left(c_{3}, G\right)=(1-\lambda) \frac{c_{3}^{1-\gamma}-1}{1-\gamma}+\lambda \frac{G^{i-\gamma}-1}{1-\gamma}
$$

where the parameter $\lambda$ controls the choice between last-period consumption and bequest. If households care about bequests, they will behave so as to leave a bequest in any state of the world. Under CRRA utility, the model cannot be solved analytically, and instead is solved numerically. The level of information cost sufficient to deter stock market participation is solved for as the (endogenous) reduction in resources sufficient to yield the same expected utility the household would receive by investment in riskless assets alone, under the assumption that the information cost is paid prior to investment in the first period, and onefourth of the cost recurs in the second period of life.

Chart 1 shows the ratio of information cost relative to first period income that would make the household indifferent between undergoing the information expense to invest in stocks, and forgoing the expense and investing in riskless assets only, for households at each of the three education levels, by degree of risk aversion. If the ratio of information cost to income falls below the plotted line, the household will be better off by undertaking the 
information expense and investing in the stock market. For any ratio of cost to income above the line, the household will not wish to undertake the information expense, and will have higher expected utility by investing only in riskless assets. The ratio of the information cost sufficient to deter investment in stocks relative to first period income is highest for collegeeducated households. Although these households have the highest first period income, the utility gains to stock market investment for these households are sufficiently large that it would take a large information expense to deter their participation. At each level of education, the income cost is a decreasing function of the degree of risk aversion. For any degree of risk aversion, the introduction of (uncorrelated) income risk lowers the information cost sufficient to deter investment. The addition of a bequest motive, however, increases the information cost. Households that care not only about their own future consumption but plan to leave a bequest as well have a greater incentive to participate in the stock market and take advantage of the expected equity premium, and consequently the information cost required to deter their participation is higher.

\section{Specifícation of the model of stock market participation}

In the standard Consumption Capital Asset Pricing Model (CCAPM), demands for each asset are determined jointly, and the specification of asset demands should consider simultaneously the portfolio choice across all possible asset combinations. When we allow for the possibility of incomplete portfolios where not all assets are held, the number of possible asset combinations is $2^{n}-1$, which becomes very large as the number of assets (n) rises. Studies which have tried to estimate the simultaneous decision have resorted to very aggregated portfolio combinations to make the estimation feasible [Uhler and Cragg (1971), King and Leape (1984), Perraudin and Sorensen (1991)]. However, if the aim is to estimate the probability of ownership of a particular asset, then a reduced-form equation which does 
not include other asset demands can be estimated separately. This approach is also used by Ioannides (1992) and Agell and Sorensen (1990).

As in the standard CCAPM, households are assumed to maximize utility of consumption, and for estimation, we assume that the household's indirect utility function can be written as a linear function of household characteristics plus an error term $u_{i}$. Let

$$
U_{1 i}=X_{1 i} \beta_{1}+u_{1 i}
$$

be the indirect utility function when households invest in the stock market, and let

$$
U_{2 i}=X_{2 i} \beta_{2}+u_{2 i}
$$

be the indirect utility function when households do not invest in the stock market.

The $X_{i}$ 's are observable variables pertaining to household i's characteristics. These include current wealth and income, and measures of the parameters of the utility function, such as degree of risk aversion, rate of time preference, and the intention of leaving a bequest. The $X_{i}$ 's also include variables that may help explain apparent underinvestment in stocks if information costs are important for the stockholding decision, such as level of education, access to financial market information, and age. The level of education may also be indicative of future income prospects, which in turn may influence portfolio decisions, as demonstrated in Bertaut and Haliassos (1996). The $u_{i}$ error terms include unobserved household-specific factors that may be important for the stockholding decision. In practice, the indirect utility function is not observable, and we instead observe a dummy variable of participation or nonparticipation in the stock market: 


$$
D_{i}=1 \text { if } U_{2 i}<U_{1 i}
$$

that is, the household's utility when holding stocks is higher than when not participating in the stock market, and

$$
D_{i}=0
$$

otherwise.

Then the probability that

$$
\begin{aligned}
D_{i} & =1 \\
& =P\left(U_{2 i}<U_{1 i}\right) \\
& =P\left(X_{2 i} \beta_{2}+u_{2 i}<X_{1 i} \beta_{1}+u_{1 i}\right) \\
& =P\left(u_{2 i}-u_{1 i}<X_{1 i} \beta_{1}-X_{2 i} \beta_{2}\right) \\
& =P\left(\varepsilon_{i}<X_{i} \beta\right) .
\end{aligned}
$$

With the assumption that the error terms $\varepsilon_{\mathrm{i}}$ are normally distributed, this dichotomous choice model can be estimated by probit maximum likelihood.

Since we have access to panel data with household portiolio choices in two years, we can specify a bivariate model and allow for unobserved heterogeneity resulting from household-specific factors with correlation $\rho$ between the disturbances for each household $i$ :

$$
\begin{aligned}
& \boldsymbol{\varepsilon}_{i t}=\mu_{i}+v_{i t} ; \boldsymbol{\varepsilon}_{i t} \sim N\left(0, \sigma^{2}\right) \\
& \mathrm{E}\left[\boldsymbol{\varepsilon}_{i t} \varepsilon_{i^{\prime} t^{\prime}}\right]=\sigma^{2} \quad \text { if } i=i^{\prime}, t=t^{\prime} \\
& =\rho \quad \text { if } i=i^{\prime}, t \neq t^{\prime} \\
& =0 \text { if } i \neq i^{\prime}
\end{aligned}
$$

If the errors are jointly normally distributed, the equations for 1983 and 1989 can be estimated by bivariate probit. The variance of $\varepsilon_{\mathrm{it}}, \sigma^{2}$, is normalized to 1 because only the ratio of $\beta / \sigma$ can be identified by probit maximum likelihood. 
The probabilities that enter the likelihood function are then given by the bivariate normal cumulative distribution function:

$$
\operatorname{Prob}\left(Y_{1}=y_{i 1}, Y_{2}=y_{i 2}\right)=\Phi\left(w_{i i}, w_{i 2}, \rho_{i}^{*}\right)=\int_{-\infty}^{w_{i 2} n_{i, 1}} \int_{-\infty} \phi\left(z_{i 1}, z_{i 2}, \rho_{i}^{*}\right) d z_{i 1} d z_{i 2}
$$

where

$$
\begin{aligned}
& w_{i 1}=\left(2 y_{i 1}-1\right) \beta_{1}{ }^{\prime} X_{i 1} \\
& w_{i 2}=\left(2 y_{i 2}-1\right) \beta_{2}{ }^{\prime} X_{i 2} \\
& \rho_{i}^{*}=\left(2 y_{i 1}-1\right)\left(2 y_{i 2}-1\right) \beta_{1}^{\prime} X_{i 1} \beta_{2}^{\prime} X_{i 2} \rho
\end{aligned}
$$

and

$$
\phi\left(w_{i l}, w_{i 2}, \rho_{i}^{*}\right)=\frac{e^{-1 / 2\left(w_{i i}^{2}+w_{i, 2}^{2}-2 \rho_{i}^{*} w_{i, 1} w_{i 2}\right) /\left(1-\rho_{i}^{*}\right)^{3}}}{2 \pi\left(1-\rho_{i} *^{2}\right)^{1 / 2}}
$$

is the bivariate normal density.

\section{Data from the $1983 / 1989$ Panei Survey of Consumer Finances}

The data set used for estimation is the 1983 and 1989 panel of the Survey of Consumer Finances. This panel data set contains detailed information on household portfolios and incomes, and respondent attitudes towards financial risk, liquidity, use of credit, and reasons for saving at two points in time. The sample used for this paper categorizes as nonstockholders in 1983 the 68 households who owned stocks only in the company in which a household member was employed, and 75 such househoids as nonstockholders in 1989. Because costs associated with acquiring such stocks are minimal compared with holding other stocks, and returns to such stocks may have different covariance properties with household labor income, the behavior of these households may distort conclusions about variables 
relevant for the decision to acquire stocks. Since we use several variables on respondent attitudes, the sample is restricted to households where the respondent is the same in both years. The resulting sample contains 1,368 households.

Because observations are available for two periods in time, we can observe the stockholding decisions of households who hold stocks in both 1983 and 1989, those who abstain from market participation in both years, and those who change stockholder status. The percentage of the sample holding stocks in 1983 (34.7 percent) is about the same as in 1989 (34.3 percent), but the composition of 1989 stockholders is not the same as in 1983 . Nearly 25 percent of the 1983 stockholders in the sample did not hold stocks in 1989, about the same percentage of 1989 stockholders who were nonstockholders in 1983 (see Table 1). ${ }^{5}$ Specifying the model as a bivariate probit allows calculation not only of the probabilities of the four alternate stock market participation categories, but also conditional probabilities of continued participation or nonparticipation.

\begin{tabular}{||lc|cc||}
\hline \multicolumn{3}{|c|}{ Table 1. Stockholder Composition in 1983 and 1989 } \\
\hline \multicolumn{1}{|c|}{1983} & \multicolumn{2}{c|}{1989} \\
& & Stockholders & Nonstockholders \\
\hline Stockholders & 475 & 358 & 117 \\
Nonstockholders & 893 & 111 & 782 \\
Total & 1368 & 469 & 899 \\
\hline
\end{tabular}

For estimation of the 1983 and 1989 stockholding decisions, the set of respondent characteristics include dummy variables for sex, race, and marital status in 1983. Respondent age is included through a set of 10-year age-range dummies to investigate whether the ability to overcome inertial reasons for nonparticipation--for example, through increased exposure to information--increases with age, or alternatively whether older households are deterred from 
stockholding by the shorter investment horizons they may face. Dummy variables for retirement in 1983, remaining retired in 1989, or becoming retired between 1983 and 1989 are included to capture these life-cycle changes.

Dummy variables are included for whether the household head had less than high school education and if the head had a high school degree but no college degree, with obtaining a college degree as the omitted dummy variable. This distinction is important for the extent to which higher education leads to greater financial sophistication and ability to acquire information necessary for market participation, but may also reflect long-run income prospects. More-educated households may have both a greater ability and incentive to overcome inertial behavior by undertaking costs associated with stock market participation, as indicated in Chart 1. Chart 1 also shows that for any level of education, the addition of income risk lowers the cost sufficient to deter stock market participation. To capture labor income risk, dummy variables are included in the bivariate probit for having an occupation with above or below average unemployment risk (see Data Appendix). A dummy variable is also included for having a managerial occupation, since managers may have smaller opportunity costs to finding out about investment opportunities from being involved in related professional activities.

Current household wealth is divided into financial and nonfinancial assets, to capture differences in portfolio decisions that may arise from liquidity considerations. Financial net worth includes relatively liquid riskless assets, directly held stocks and shares in mutual funds, bonds, trusts and other managed accounts, IRAs, and the cash value of life insurance, minus the total outstanding on consumer loans. Nonfinancial net worth includes investment 
in real estate, automobiles and other consumer durables, net of any loans outstanding for these assets. For both financial and nonfinancial net worth, the probit regression uses the log of the value. Current labor income is estimated as wage and salary income, income derived from a professional business or practice, unemployment or worker's compensations payments, and income from Social Security and other pensions, and is also included as the log of its value.

Dummy variables are included for self-expressed risk aversion, measured by the individual's responses to questions in each year of how much financial risk he was willing to take for commensurate financial return. Households are coded as "willing to take above average or substantial risk to receive above average or substantial expected return," "average risk to receive average return," and the omitted dummy is "not willing to take any financial risk." As the calibrations in Chart 1 show, the utility gain from stock market participation is smaller for agents with greater risk aversion, so these agents can be deterred from participation by relatively low costs of acquiring information. In a non-expected utility framework that allows for "first-order risk aversion," households can be deterred from stock market participation even if information is costless to them because their utility functions are not differentiable at zero stock investmenti (Yaaari (1987), Segal and Spivak (1990), and Haliassos and Bertaut (1995)). Dummy variables are also included for whether the household considered itself to be credit constrained. Although Haliassos and Bertaut (1995) find that a restriction on borrowing against future income alone is not sufficient to deter market participation, ${ }^{6}$ relatively small information costs are required to eliminate utility gains from participation by individuals for whom the constraint is binding. (Bertaut, 1993). Following Cox and Jappelli (1993), a household was coded as being credit constrained if the respondent 
indicated that a request for credit had been denied, or less credit than requested had been granted, and the household did not subsequently receive the desired amount of credit $\supset$ elsewhere, or if the household did not apply for credit because it was expected that such a request would be denied.

For both years, a dummy variable is included for whether or not the respondent stated that credit card balances were always paid in full. Paying off credit card balances could reflect either an absence of liquidity constraints or may be a measure of financial astuteness. ${ }^{7}$ Dummy variables are included for whether the majority of wealth was inherited (in 1983) or whether a sizable bequest was received (in 1989), and whether the household planned to leave a bequest (in 1989). Stocks may be especially desirable assets for households with bequest motives, because capital gains on bequeathed stocks escape taxation. As illustrated in Chart 1, adding a bequest motive increases the information cost necessary to deter stock market investment. Additionally, if an inheritance received was partly in the form of stocks, the household need not overcome initial inertial behavior to invest, and may continue to participate in the market with little additional expenditure on information.

Although the holding period does not matter for the standard CCAPM, a typical rule of thumb is that stocks are considered a superior investment to bonds for households with investment horizons of five years or more. Dummy variables are included for whether the respondent indicated willingness to tie up funds to achieve above average financial return (in 1983) and for having a main financial planning period of five or more years (in 1989). ${ }^{8}$

Use of the panel data set allows for observation of life-style changes that may affect portfolio decisions. In addition to the variables on becoming or remaining retired, dummy 
variables are included for acquiring a new primary job or losing the 1983 primary job.

Dummy variables are also included for changes in marital status: remaining married to the same spouse as in 1983; becoming married between 1983 and 1989; and becoming divorced, widowed, or separated between the survey years. The omitted dummy is remaining single. Respondents who became married could increase stock ownership from marrying someone who is already a stockholder, or from an increased interest in planning for the future. We also include variables measuring the (log of) the amount spent on financing education between 1983 and 1989 and for whether the household bought a house during that period. These major expenses could be reasons for exiting the stock market.

Details of all the explanatory variables are included in the Data Appendix. Table 2 gives the characteristics of three composite respondents. A median or "typical" respondent has all variables taken at their population median values. 'This "typical" respondent has a high school education, is willing to take average financial risk ${ }^{10}$, has a low unemployment-risk occupation, does not pay off credit card balances, did not inherit wealth, and does not intend to leave a bequest. The typical respondent is contrasted with composite individuals who have the characteristics at the 25 th percentile and the 75 th percentile of the population. In contrast to the median household, the 25 th percentile household is younger, is not willing to take any financial risk, has an average unemployment-risk occupation, and lower financial and nonfinancial wealth and labor income. The composite household at the 75 th percentile is older, has college education, pays off credit card balances, plans to leave a bequest, and has higher labor income and wealth. 


\section{Results from the 1983 and 1989 bivariate probit}

\subsection{Coefficient estimates}

Table 3 presents the parameter estimates from the 1983-1989 bivariate probit regression. In both years, the parameter estimates for both financial and nonfinancial net worth are positive and significant. Non-financial wealth has a larger coefficient than financial wealth in 1983 and a smaller coefficient 1989, suggesting no special role for the liquidity of assets in predicting stock market participation. Household labor income is not significant in either year. Results for variables capturing unemployment risk provide limited support for the notion that labor income risk can influence market participation. Having an occupation with below average unemployment risk has a positive coefficient significant at the 9 percent level in 1983, but an insignificant coefficient in 1989. The coefficient on having an occupation with above average unemployment risk is not significant in either year. Having a managerial occupation has an additional significant positive coefficient in 1983 but not 1989, suggesting perhaps that the information benefits of a managerial job were no longer present by 1989 .

All the dummy variables for education are highly significant, with higher levels of education increasing the predicted probability of ever being a stockholder. The strength of these results even after controlling for wealth, current income, and unemployment risk, suggests that education captures a measure of the ability to process information about the market and investment opportunities. However, because the level of education may also serve as a proxy for future expected resources, it is not possible to disentangle these two effects.

The coefficients for both the dummy variable indicators of risk aversion (willingness to take above average or significant risk for above average or significant financial retum, and 
willingness to take average risk for average return) are significantly different from the omitted dummy (not willing to take any financial risk) and from each other in both years. Caution should be used in interpreting these results, however, because there is considerable evidence that self-expressed classifications of risk aversion are imperfect indicators of the respondent's actual degree of risk aversion. Individuals may be describing their "ideal" portfolio, rather than portfolio choices they actually face. ${ }^{11}$ In addition, these respondent attitudes were not always consistent over time. Many fewer sample households declared they were willing to take above average or substantial risk in 1989 , with nearly half of those giving this answer in 1983 switching to average risk in 1989. Additionally, about 34 percent of those willing to take average risk in 1983 were not willing to take any risk in 1989. Although some of these households that switched risk aversion category may have had adverse stock return realizations from the 1987 stock market drop, the majority of those switching from average risk to not willing to take risk were nonstockholders in both years, while the majority of households that switched from above average risk to average risk were stockholders in both years. $^{12}$

The coefficients on the age-range dummies increase with each age range, but are significant at least at the 10 percent level only for ages 45 and above in 1983, and 55 and above in 1989 . In both years, the coefficient is largest and most significant (at the 1 percent level) for age 75 and above. These results support the notion that increased exposure to information about the stock market can help overcome inertial behavior, and suggest that older households are not deterred by shorter investment horizons. Neither sex, race, nor 1983 marital status are significant. 
Considering oneself to be credit constrained has a positive coefficient in 1983 and a negative coefficient in 1989 , but neither are significant. In contrast, the coefficients on always paying off credit card balances are significant and positive in both years. Paying off credit card balances may be a more objective measure of financial liquidity, or it may be indicative of financial sophistication and the ability to weigh financial costs and benefits. Mixed information is given by the coefficients on inheritance of the majority of wealth. The coefficient for inheritance of the majority of wealth in 1983 is significant at the five percent level, with a coefficient larger than that of paying off credit cards or having a managerial occupation. However, inheriting assets has an insignificant coefficient in 1989. Although most households who had inherited assets in 1989 had not claimed that the majority of their saving came from inheritance in 1983, this does not appear to explain any entry into the stock market between the two years. Expressing an intention to leave a bequest (asked only in 1989) has a significant positive coefficient. ${ }^{13}$ Neither of the variables reflecting the willingness to tie up funds or financial planning horizon are significant.

Variables that reflect major life changes between 1983 and 1989 provide some interesting results. Although 1983 marital status is insignificant, becoming married contributes significantly to the probability of holding stocks in 1989, suggesting that acquisition of assets through family change may be important. Remaining single, remaining married to the same spouse, or becoming divorced, widowed or separated has no effect. Results are somewhat puzzling for changes to labor force status. Acquiring a new main job has a negative but insignificant coefficient, while losing the previous main job has a positive but insignificant coefficient. However, becoming retired between 1983 and 1989 had a large, 
positive, and significant coefficient. Although this result is intriguing, it is contrary to other indications of life-cycle behavior from the 1983-1989 Panel Survey (Kennickell and StarrMcCluer (1996)). Further examination of the data reveal that the majority of respondents in this category were less than 65 years old in 1989 . Early retirement may be more feasible for households who have accumulated sufficient wealth through stock market participation. ${ }^{14}$ Neither education expense nor buying a house have significant coefficients.

The estimate of $\rho$, the correlation between error terms for each household, is quite large (.501), and the null hypothesis that individuals are not subject to individual-specific random shocks can be rejected with very high probability by both a Wald test on $\rho$ and a likelihood ratio test. ${ }^{15}$

\subsection{Predicted probabilities of stock market participation}

Chart 2 shows the predicted probability of falling into the four stockholding categories for the composite 25 th percentile, median, and 75 th percentile respondents. The first set of bars shows the probability of being a nonstockholder in both years. The second and third sets of bars give the probabilities of being a stockholder in 1983 but a nonstockholder in 1989, or a nonstockholder in 1983 and a stockholder in 1989. Finally, the fourth set gives the probability of being a stockholder in both years. The combination of greater wealth, higher education, managerial occupation, and greater willingness to take financial risk makes a very large difference in the predicted probability of holding stocks. For an individual with median characteristics, the predicted probability of being a stockholder in both years (the fourth set of bars) is only .06 , while the probability of abstaining from market participation in both years (the first set) is .75 . For a household with characteristics at the 75 th percentile, the predicted 
probability of holding stocks in both 1983 and 1989 is .49 , while the probability of holding stocks in neither year is 20 . In contrast, having characteristics of the 25 th percentile generates a probability of less than .01 for participation in both years, and .99 for participation in neither year.

Charts 3a-3d show the effects of changing only one characteristic on predicted probabilities for the median respondent. Chart 3a shows how different levels of financial net worth alone affect the probability of falling in the four stockholder categories for a respondent with all other characteristics taken at the population median values. A substantially higher level of financial wealth, increasing from $-\$ 215$ (the level of financial wealth for the 25 th percentile household) to $\$ 19,547$ (the level for the 75 th percentile) in 1983 and from $\$ 3,260$ to $\$ 48,910$ in 1989 , reduces the probability that an otherwise typical household will not be a stockholder in either year from .83 to .72 , and slightly raises the probability of being a stockholder in at least one year.

Chart $3 \mathrm{~b}$ shows how changing only risk aversion affects the probability of falling in the four stockholder categories for the median household. For the median household, high risk aversion raises the probability of being a nonstockholder in both years to .88 , and reduces the probability of falling into any of the other categories. Being willing to take above average or substantial financial risk reduces the probability of never holding stocks to .67 , and raises each of the three other categories slightly.

Chant $3 c$ shows the effect of changing only the level of education for the median respondent. An increase in education from less than high school to college graduate raises 
the probability of holding stocks in both years from .01 to .15 , and lowers the probability of not holding stocks in either year from .91 to .57 .

In contrast to the effects generated by differences in income, education, or risk aversion, a value of $\rho$ even two standard deviations from the mean value would have little effect on the predicted probabilities of falling into the four stockholding categories. Chart $3 \mathrm{~d}$ shows these effects for the median respondent. A higher value of $\rho$, indicating a greater correlation in the random disturbances, slightly increases the probability of being observed as either a consistent stockholder or a consistent nonstockholder, while a lower value of $\rho$ slightly lowers the probability of consistent behavior.

\subsection{Conditional Probabilities of Entering and Leaving the Stock Market}

Charts 2-3 in the previous section illustrated how the probabilities of falling into the four different stockholder categories are influenced by different levels of education, risk aversion, and financial net worth. The composite 25 th percentile and median households were overwhelmingly likely to be predicted as nonstockholders in both 1983 and 1989, while for the 75th percentile household, being a stockholder in both years had the highest predicted probability. A somewhat different question to ask is how likely is a 1983 nonstockholder to continue to be a nonstockholder in 1989 , compared with the probability of becoming a stockholder. Conditional probabilities can be estimated from the bivariate normal results as

$$
\operatorname{Prob}\left(Y_{2}=y_{i 2} \mid Y_{1}=y_{i 1}\right)=\frac{\operatorname{Prob}\left(Y_{1}=y_{i 1}, Y_{2}=y_{i 2}\right)}{\operatorname{Prob}\left(Y_{1}=y_{i 1}\right)}
$$

where $\operatorname{Prob}\left(Y_{1}=y_{i 1}\right)$ is derived from the univariate normal c.d.f. of the 1983 equation. 
Chart 4 provides information on these conditional probabilities. The first two sets of bars show the conditional probabilities that nonstockholders in 1983 will continue to abstain from market participation, or enter the stock market between 1983 and 1989. The second two sets show the probabilities that 1983 stockholders will leave the stock market between 1983 and 1989, or remain in the stock market in both years. This chart illustrates the persistent behavior of household portfolio decisions. Perceived initial set-up costs of information and other factors that can deter investment make it unlikely that a typical household will enter the market between 1983 and 1989 . However, if households made the initial information expense and participated in the market in 1983 , the probability of remaining a stockholder is fairly high, even though information or monitoring costs may recur each year. The predicted probability that a nonstockholder with median characteristics in 1983 will remain a nonstockholder in 1989 is large $(.87)$, while probability that a stockholder with median characteristics in 1983 will remain a stockholder in 1989 is also relatively large (.43), even though the initial probability of holding stocks in 1983 is small. For a nonstockholder household with characteristics at the 25 th percentile, the probability of remaining a nonstockholder is almost 1. In addition, the combination of lower education, less willingness to undertake financial risk, and lower wealth -- characteristics that reduce both the ability and incentive to keep up with market developments important for continued participation -- lowers the conditional probability to .23 that a 1983 stockholder with characteristics of the 25 th percentile will still be a stockholder in 1989. However, a nonstockholder with characteristics at the 75 th percentile in 1983 is slightly more likely to have become a stockholder by 1989 
than to remain a nonstockholder. For these households, the incentive to overcome inertial behavior can be sufficient to lead to eventual entry into the market.

Chart 5a shows the effect of different levels of financial net worth, holding all other characteristics constant, on the conditional probabilities of entering and leaving the stock market for the median respondent. Although 1983 nonstockholders are likely to remain nonstockholders, greater wealth increases the probability that nonstockholder respondents will become stockholders by 1989 , and reduces the probability that 1983 stockholders will leave the stock market by 1989. Giving the median respondent levels of financial wealth at the 25 th percentile produces some interesting results. Because the 25 th percentile household experiences a shift from negative financial net worth in 1983 to positive financial net worth in 1989, this increase in financial net worth slightly increases the probability that a 1983 nonstockholder will become a stockholder by 1989, and considerably increases the probability that a 1983 stockholder will remain a stockholder in 1989 . Increased willingness to take financial risk reduces the conditional probability that a nonstockholder household will remain a nonstockholder in 1989 (Chart 5b), and increases the probability that a 1983 stockholder will remain a stockholder in 1989. The effects of different levels of education on the conditional probabilities are shown in Chart 5c. Having a college education increases the predicted probability that a 1983 non-stockholder will become a stockholder by 1989 , while 1983 stockholders with less than high school education have a higher predicted conditional probability of leaving the market than continuing as stockholders.

In contrast to the limited effect of changes in the correlation $\rho$ illustrated in Chart $3 \mathrm{~d}$, values of $\rho$ two standard deviations from the mean value have more evident effects on the 
conditional probabilities of remaining a stockholder or nonstockholder. Higher values of correlation between the individual-specific error terms (larger values of $\rho$ ) raise the probability of persistent behavior, while smaller values raise the probability that the individual will change stockholder status. These effects on the conditional probabilities are illustrated in Char 5d.

\section{Concluding remarks}

Results from panel data for 1983 and 1989 show that most U.S. households demonstrate considerable persistence in their portfolio investments. Households that chose to hold riskless assets but not stocks may do so because they perceive the information required for participation to be costly relative to the benefits received. Factors such as increased risk aversion, income risk, and lower resources can reduce the utility gains from market participation, and reduce the level of information cost that would be sufficient to deter households from stock investment. Formal econometric analysis shows that households with lower wealth and higher risk aversion are less likely to hold stocks in both 1983 and 1989. The hypothesis that information costs are an important reason for the apparent underinvestment in stocks is supported by the finding that factors such as age, education, managerial occupation, and inheritance of assets are all significant in explaining the probability of holding stocks.

The results for conditional probabilities are also consistent with the idea that the ability to overcome inertial behavior is an important explanation for portfolio allocation. Most households are nonstockholders and are likely to remain nonstockholders. Households 
with greater willingness to undertake financial risk, higher education, and greater wealth who nonetheless had not overcome inertial behavior to enter the stock market by 1983 have a much increased likelihood of entering the stock market by 1989. Households with lower resources, more limited education, and less willingness to take financial risk who owned stocks in 1983 are more likely to have dropped out the market by 1989 , perhaps because the ongoing costs of monitoring the investments are perceived to be too high relative to the expected benefits of participation. With the exception of becoming married between 1983 and 1989, few life-style changes appear to explain changes in stockholder status.

Financial advisors suggest that all households should invest in the stock market, although the proportion of the portfolio invested in stocks may vary according to investment horizon and tolerance for financial risk. However, despite the growth of mutual stock funds, most households in 1992 still did not participate in the stock market. If there is an increasing trend to require individuals to plan for their own financial futures, perhaps because of expected inadequacies of Social Security and private pensions, the results presented here suggest that education and advertising campaigns can be instrumental in helping households overcome reluctance to hold stocks caused by insufficient information about the benefits, risks, and costs of market participation. 


\section{References}

Abel, Andrew B. "The Equity Premium Puzzle" Federal Reserve Bank of Philadelphia Business Review, (Sept-Oct 1991): pp. 3-14.

Agell, J. and P.-A. Edin. "Marginal Taxes and the Asset Portfolios of Swedish Households" Scandinavian Journal of Economics, vol. 92 (1990): pp. 47-67.

Aiyagari, S. Rao and Mark Gertler. "Asset Returns with Transactions Costs and Uninsured Individual Risk: A Stage III Exercise" Journal of Monetary Economics, vol. 27 (1991): pp. 311-331.

Bertaut, Carol C. and Michael Haliassos. "Precautionary Portfolio Behavior from a Life-Cycle Perspective," International Finance Discussion Paper 542, Board of Governors of the Federal Reserve System, 1996; forthcoming Journal of Economic Dynamics and Control.

Bertaut, Carol C. "Stockholding Behavior in the United States: A Theoretical and Empirical Investigation." Unpublished PhD. dissertation, University of Maryland, 1993.

Cox, Donald and Tuilio Jappelili. "The Effect of Borrowing Constraints on Consumer Liabilities," Journal of Money, Credit, and Banking, Vol. 25, No. 2 (1993).

Epstein, Larry G. and Stanley E. Zin. "First-order Risk Aversion and the Equity Premium Puzzle" Journal of Monetary Economics, vol. 26 (1990): pp. 387-407.

Feldstein, M. S. "Personal Taxation and Portfolio Composition: An Econometric Analysis" Econometrica, vol. 44 (1976): pp. 631-650.

Greene, William H. Econometric Analysis, second edition. Macmillan: New York (1993).

Haliassos, Michael and Carol Bertaut. "Why Do So Few Hold Stocks?" The Economic Journal, vol. 105 (1995), pp. 1110-1129.

Haliassos, Michael and Andrew Lyon, "Progressivity of Capital Gains Taxation with Optimal Portfolio Selection", In J. Slemrod (Ed.), Tax Progressivity and Income Inequality. Cambridge: Cambridge University Press (1994).

Hubbard, Glenn, Jonathan Skinner, and Steven Zeldes. (1995). "Precautionary Saving and Social Insurance." Journal of Political Economy, vol. 103, pp. 360-399.

Hubbard, Glenn, Jonathan Skinner, and Steven Zeldes. (1994). "The Importance of Precautionary Motives in Explaining Individual and Aggregate Saving." CarnegieRochester Conference Series on Public Policy, vol. 40, pp. 59-125. 
Ioannides, Yannis. "Dynamics of the Composition of Household Asset Portfolios and the Life Cycle" Applied Financial Economics, vol. 2 (1992): pp. 145-159.

Kennickell, Arthur and Martha Starr-McCluer, "Household Saving and Portfolio Change: Evidence from the 1983-89 SCF Panel" mimeo, Federal Reserve Board of Governors, March 1996.

Kennickell, Arthur, Martha Starr-McCluer, and Annika Sunden. "Saving and Financial Planning: Some Findings from a Focus Group." Finance and Economics Discussion Series, 96-1, Board of Governors of the Federal Reserve System, (1996).

Kennickell, Arthur and Janice Shack-Marquez. "Changes in Family Finances from 1983 to 1989: Evidence from the Survey of Consumer Finances" Federal Reserve Bulletin, vol. 78 (January 1992): pp. 1-18.

Kimball, Miles S. and Matthew D. Shapiro. "A Survey-Based Measure of Individuals' Risk Tolerance: Statistical Properties and Optimal Survey Design" mimeo, University of Michigan, (1995).

King, Mervyn A. and Jonathan I. Leape. "Asset Accumulation, Information, and the Life Cycle" N.B.E.R. Working Paper No. 2392, September 1987.

King, Mervyn A. and Jonathan I. Leape. "Wealth and Portfolio Composition: Theory and Evidence" N.B.E.R. Working Paper No. 1468, September 1984.

Maddala, G. S. Limited Dependent and Qualitative Variables in Econometrics. Cambridge University Press: Cambridge (1983).

Mankiw, N. Gregory and Stephen Zeldes. "The Consumption of Stockholders and Nonstockholders" Journal of Financial Economics, vol. 29 (1991): pp. 97-112.

Mehra, Rajnish and Edward C. Prescott. "The Equity Premium: A Puzzle" Journal of Monetary Economics, vol. 15 (1985): pp. 145-161.

Newey, Whitney. "Efficient Estimation of Limited Dependent Variables with Endogenous Explanatory Variables" Journal of Econometrics, vol. 36 (1987): pp. 231-250.

Perraudin, W. R. M. and B. E. Sorensen. "Imperfect Capital Markets, Heterogeneous Investors and the Demand for Risky Assets" Brown University Working Paper No. 91-28, September 1991.

Poterba, James and Andrew Samwick. "Stock Ownership Patterns, Stock Market Fluctuations, and Consumption" Brookings Papers on Economic Activity, Macroeconomics 2:95. 
Segal, Uzi and Avia Spivak. "First Order versus Second Order Risk Aversion" Journal of Economic Theory, vol. 51 (1990): pp. 111-125.

Starr-McCluer, Martha. "Self Reported Risk Preference." mimeo, Board of Governors of the Federal Reserve System, September 1995.

Uhler, R. S. and J. C. Cragg. "The Structure of the Asset Portfolios of Households" Review of Economic Studies, vol. 38 (1971): pp. 341-357.

Yaari, Menahem E. "The Dual Theory of Choice Under Risk" Econometrica, vol. 55 (1987): pp. 95-115. 


\begin{tabular}{|c|c|c|c|}
\hline & 25th Percentile & Median (50th) & 75th Percentile \\
\hline Age & 39 & 52 & 66 \\
\hline Sex & Female & Male & Male \\
\hline Race & White & White & White \\
\hline Education & High School & High School & College \\
\hline Marital status in 1983 & Unmarried & Married & Married \\
\hline Retired in 1983 & No & No & No \\
\hline Manager in 1983 & No & No & No \\
\hline Unemployment risk for occupation in 1983 & Average & Low & Low \\
\hline Willingness to take financial risk in 1983 & Not willing & Average & Average \\
\hline Labor income in 1983 & $\$ 9,700$ & $\$ 19,000$ & $\$ 32,000$ \\
\hline Financial Net Worth in 1983 & $-\$ 215$ & $\$ 3,096$ & $\$ 19,547$ \\
\hline Non-financial net worth in 1983 & $\$ 3,300$ & $\$ 28,000$ & $\$ 74,000$ \\
\hline Always pay off credit card baiance in 1983 & No & No & Yes \\
\hline Credit constrained in 1983 & No & No & No \\
\hline Inherited majority of wealth in 1983 & No & No & No \\
\hline Willing to trade liquidity for return in 1983 & No & No & Yes \\
\hline Manager in 1989 & No & No & No \\
\hline Unemployment risk for occupation in 1989 & Average & Low & Low \\
\hline Willingness to take financial risk in 1989 & Not willing & Average & Average \\
\hline Labor income in 1989 & $\$ 12,000$ & $\$ 25,000$ & $\$ 45,000$ \\
\hline Financial Net Worth in 1989 & $\$ 3,260$ & $\$ 9,910$ & $\$ 48,910$ \\
\hline Non-financial net worth in 1989 & $\$ 2,300$ & $\$ 42,000$ & $\$ 102,000$ \\
\hline Always pay off credit card balance in 1989 & No & No & Yes \\
\hline Credit constrained in 1989 & No & No & No \\
\hline Received substantial inheritance in 1989 & No & No & Yes \\
\hline Financial planning horizon $>5$ years in 1989 & No & No & Yes \\
\hline Intend to leave a bequest & No & No & Yes \\
\hline Married to same spouse in 1989 & No & Yes & Yes \\
\hline Married between $1983-89$ & No & No & No \\
\hline Divorced/widowed/separated between 1983-89 & No & No & No \\
\hline Lost primary job $1983-89$ & No & No & No \\
\hline New primary job $1983-89$ & No & No & Yes \\
\hline Became retired between 1983-89 & No & No & No \\
\hline Remained retired in 1989 & No & No & No \\
\hline Actual education expense $1983-89$ & 0 & 0 & 0 \\
\hline Bought a house 1983-89 & No & No & No \\
\hline
\end{tabular}




\begin{tabular}{|c|c|c|c|c|c|c|}
\hline & & 83 equatio & & & 89 equatio & \\
\hline & Beta & $\begin{array}{c}\text { Standard } \\
\text { Error }\end{array}$ & T-ratio & Beta & $\begin{array}{l}\text { Standard } \\
\text { Error }\end{array}$ & T-ratio \\
\hline Intercept & -4.333 & 0.614 & -7.053 & -3.015 & 0.511 & -5.895 \\
\hline Age $35-44$ & 0.629 & 0.457 & 1.377 & 0.031 & 0.369 & 0.084 \\
\hline Age $45-54$ & 0.850 & 0.451 & 1.886 & 0.366 & 0.365 & 1.003 \\
\hline Age $55-64$ & 0.953 & 0.454 & 2.101 & 0.611 & 0.365 & 1.677 \\
\hline Age $65-74$ & 1.168 & 0.463 & 2.524 & 0.666 & 0.378 & 1.763 \\
\hline Age 75 and over & 1.363 & 0.475 & 2.871 & 1.051 & 0.400 & 2.631 \\
\hline Sex: Male & 0.239 & 0.173 & 1.383 & -0.017 & 0.228 & -0.073 \\
\hline Race: White & 0.078 & 0.169 & 0.461 & 0.149 & 0.184 & 0.810 \\
\hline Education: LTHS & -1.012 & 0.202 & -5.001 & -1.117 & 0.207 & -5.407 \\
\hline Education: HS & -0.506 & 0.108 & -4.702 & -0.443 & 0.110 & -4.044 \\
\hline Married in 1983 & -0.137 & 0.153 & -0.895 & & & \\
\hline Managerial Occupation & 0.219 & 0.112 & 1.962 & 0.042 & 0.139 & 0.301 \\
\hline Low unemployment risk occupation & 0.314 & 0.182 & 1.726 & 0.157 & 0.143 & 1.094 \\
\hline High unemployment risk occupation & -0.055 & 0.356 & -0.155 & 0.200 & 0.413 & 0.484 \\
\hline Retired in 1983 & 0.445 & 0.190 & 2.339 & & & \\
\hline Take above average financial risk & 0.651 & 0.147 & 4.423 & 0.704 & 0.153 & 4.605 \\
\hline Take average financial risk & 0.387 & 0.122 & 3.172 & 0.493 & 0.116 & 4.237 \\
\hline In Labor income & 0.056 & 0.037 & 1.486 & 0.016 & 0.022 & 0.726 \\
\hline In Financial net worth & 0.053 & 0.008 & 6.646 & 0.069 & 0.010 & 7.032 \\
\hline In Non-financial net worth & 0.101 & 0.023 & 4.473 & 0.033 & 0.015 & 2.247 \\
\hline Pay off credit card balances & 0.252 & 0.109 & 2.322 & 0.350 & 0.112 & 3.131 \\
\hline Credit constrained & 0.051 & 0.198 & 0.260 & -0.148 & 0.206 & -0.719 \\
\hline Inherited wealth & 0.349 & 0.171 & 2.048 & 0.097 & 0.097 & 0.994 \\
\hline Tie up funds/long term planning & 0.156 & 0.105 & 1.493 & 0.027 & 0.096 & 0.282 \\
\hline Intend to leave bequest & & & & 0.246 & 0.109 & 2.261 \\
\hline Married to same in 1989 & & & & 0.214 & 0.192 & 1.111 \\
\hline Married between 1983-89 & & & & 0.454 & 0.231 & 1.965 \\
\hline Divorced/widowed/separated 1983-89 & & & & -0.088 & 0.230 & -0.383 \\
\hline Lost primary job $1983-89$ & & & & 0.204 & 0.253 & 0.806 \\
\hline New primary job $1983-89$ & & & & -0.261 & 0.247 & -1.055 \\
\hline Became retired between $1983-89$ & & & & 0.627 & 0.313 & 2.004 \\
\hline Remained retired in 1989 & & & & 0.056 & 0.190 & 0.295 \\
\hline In actual education expense $1983-89$ & & & & 0.016 & 0.011 & 1.446 \\
\hline Bought house $1983-89$ & & & & 0.032 & 0.123 & 0.260 \\
\hline$\rho$ & 0.501 & 0.053 & 9.436 & & & \\
\hline \multicolumn{7}{|l|}{ log likelihood $=-989.6899$} \\
\hline
\end{tabular}




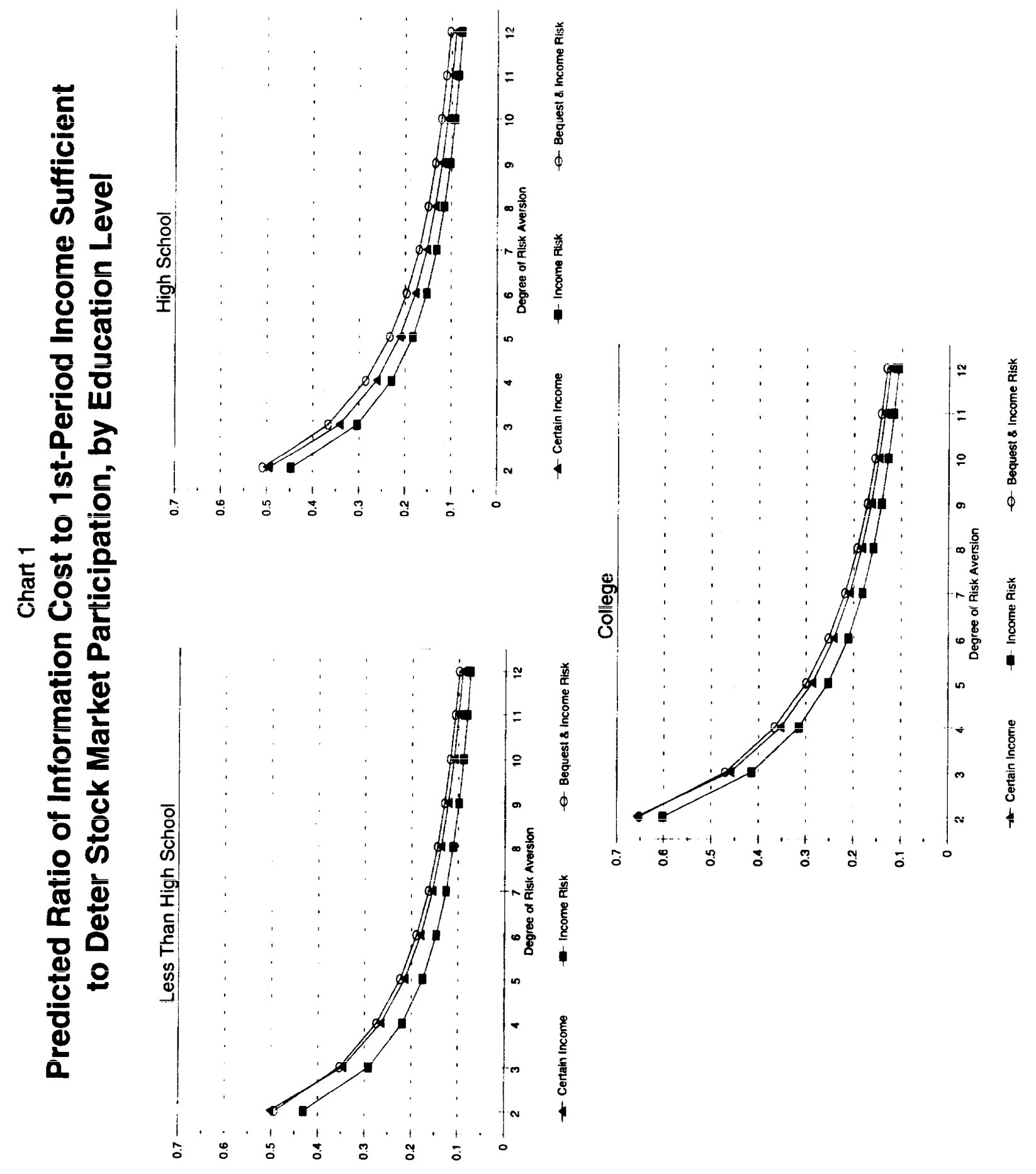




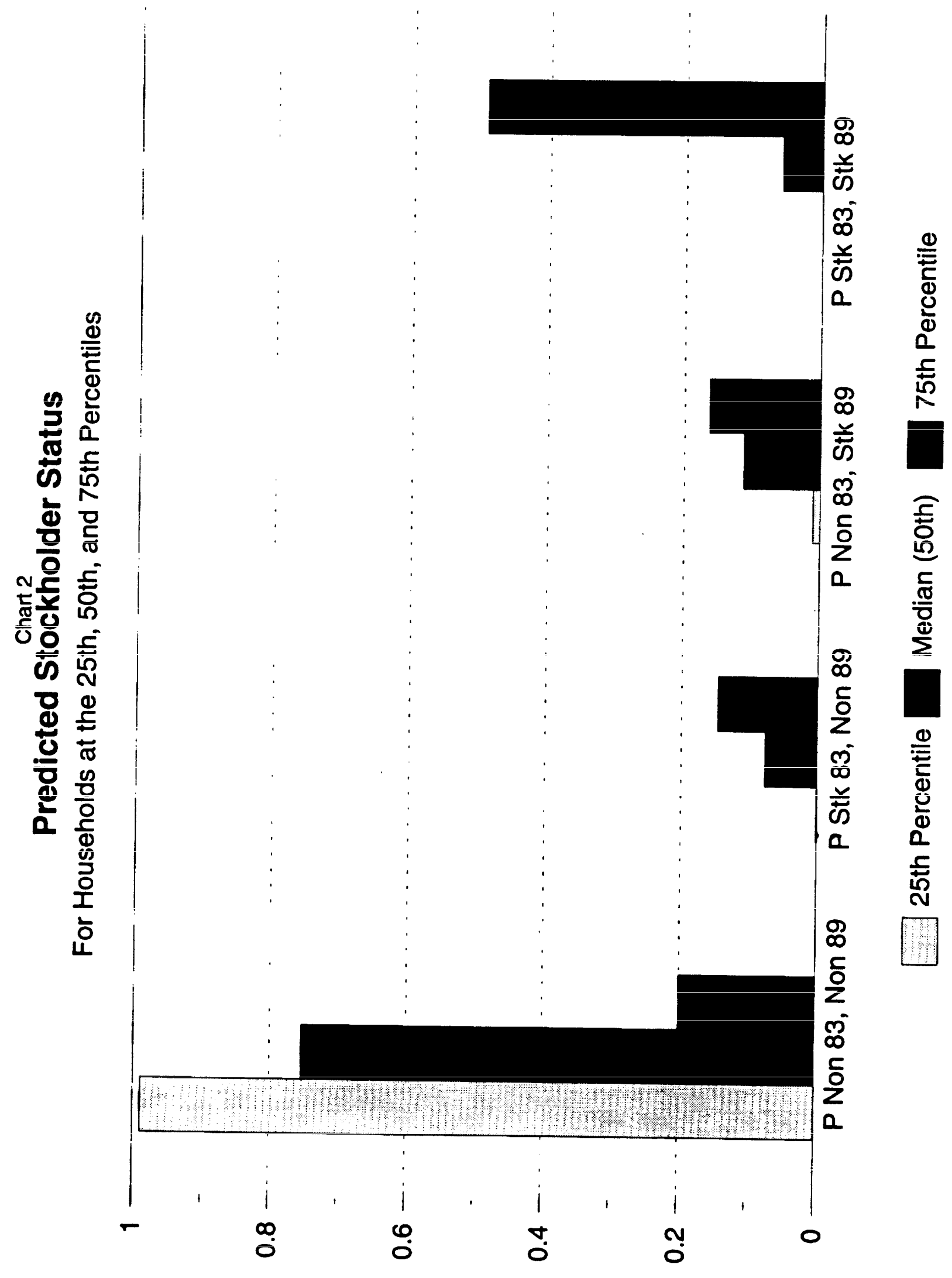




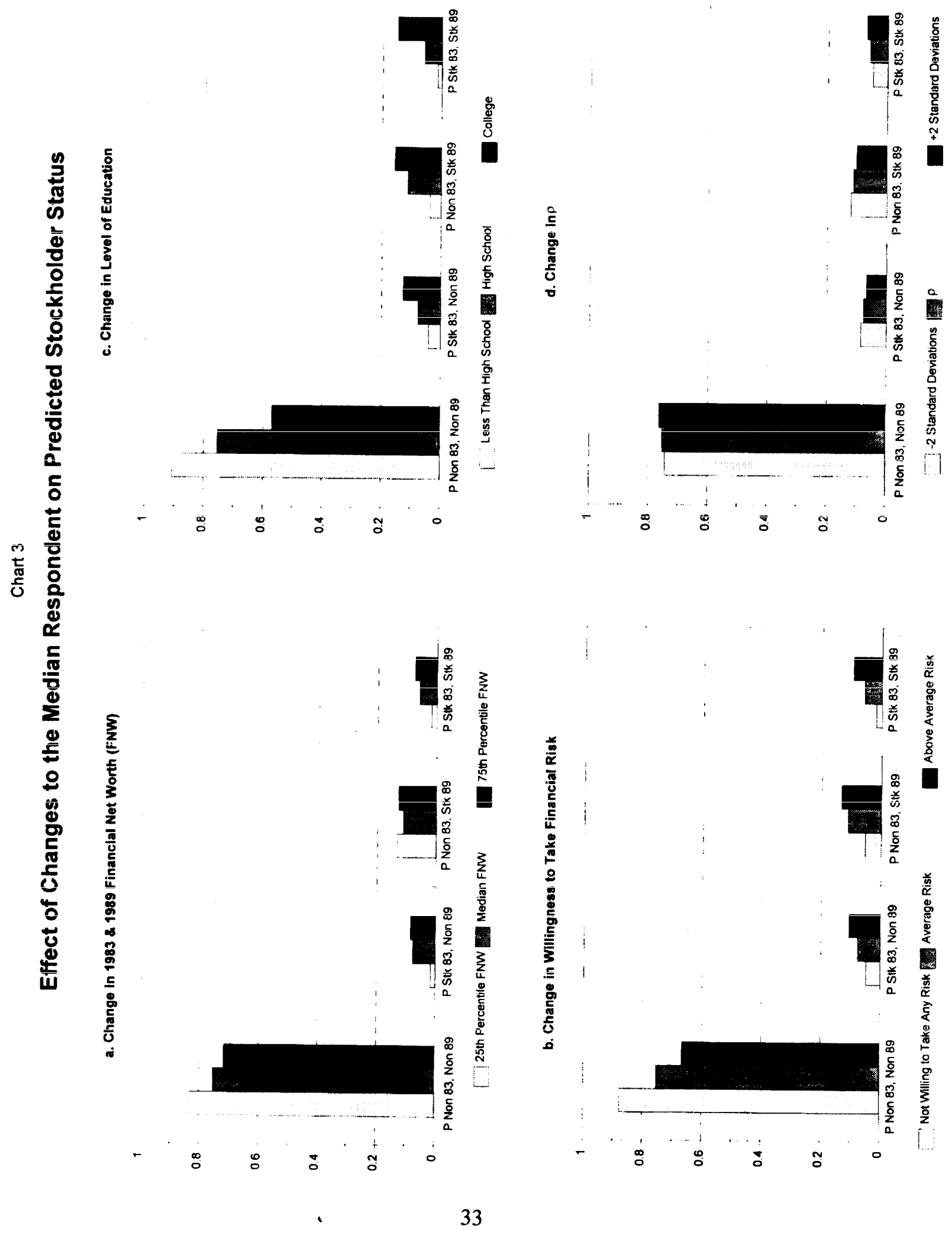




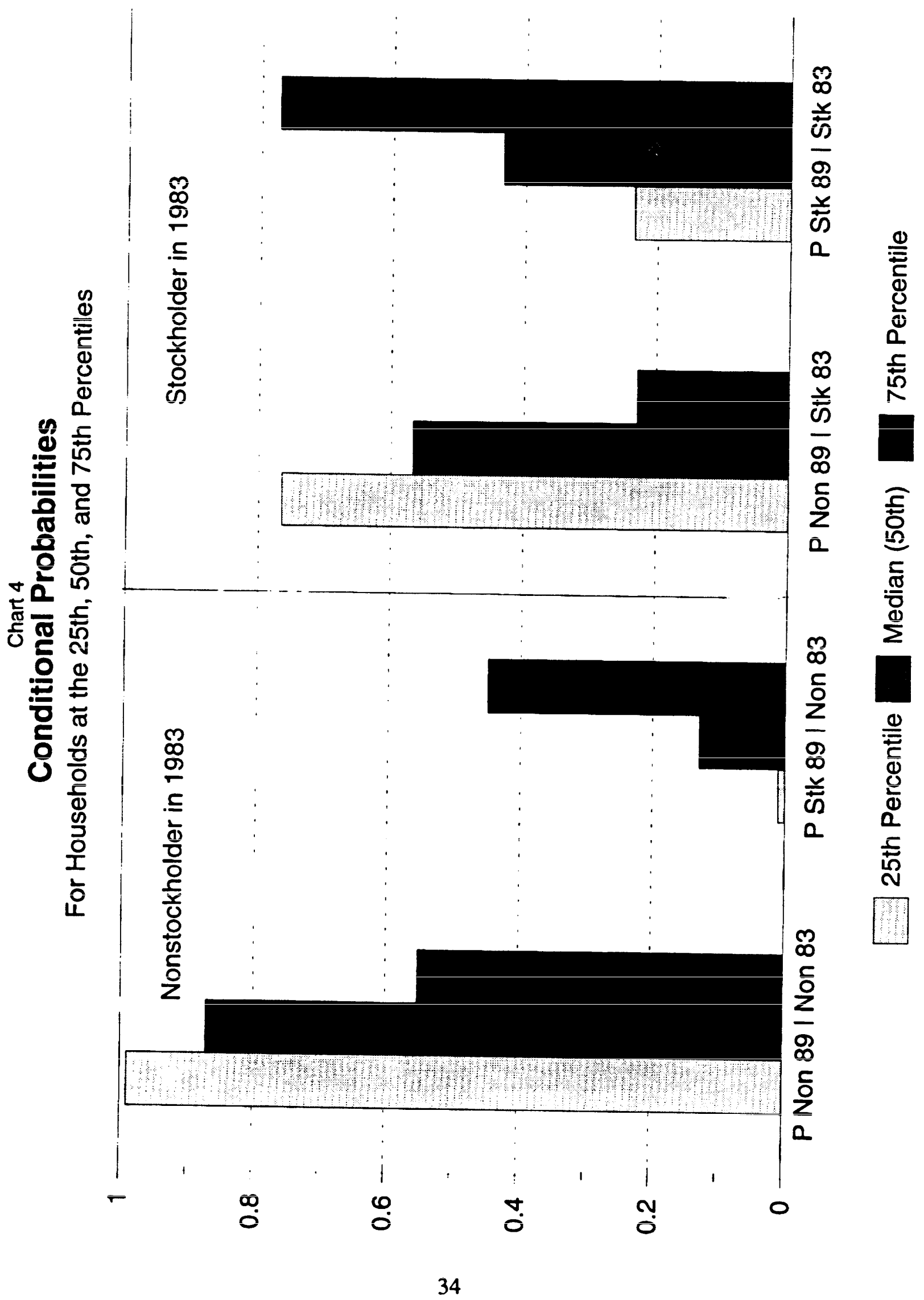




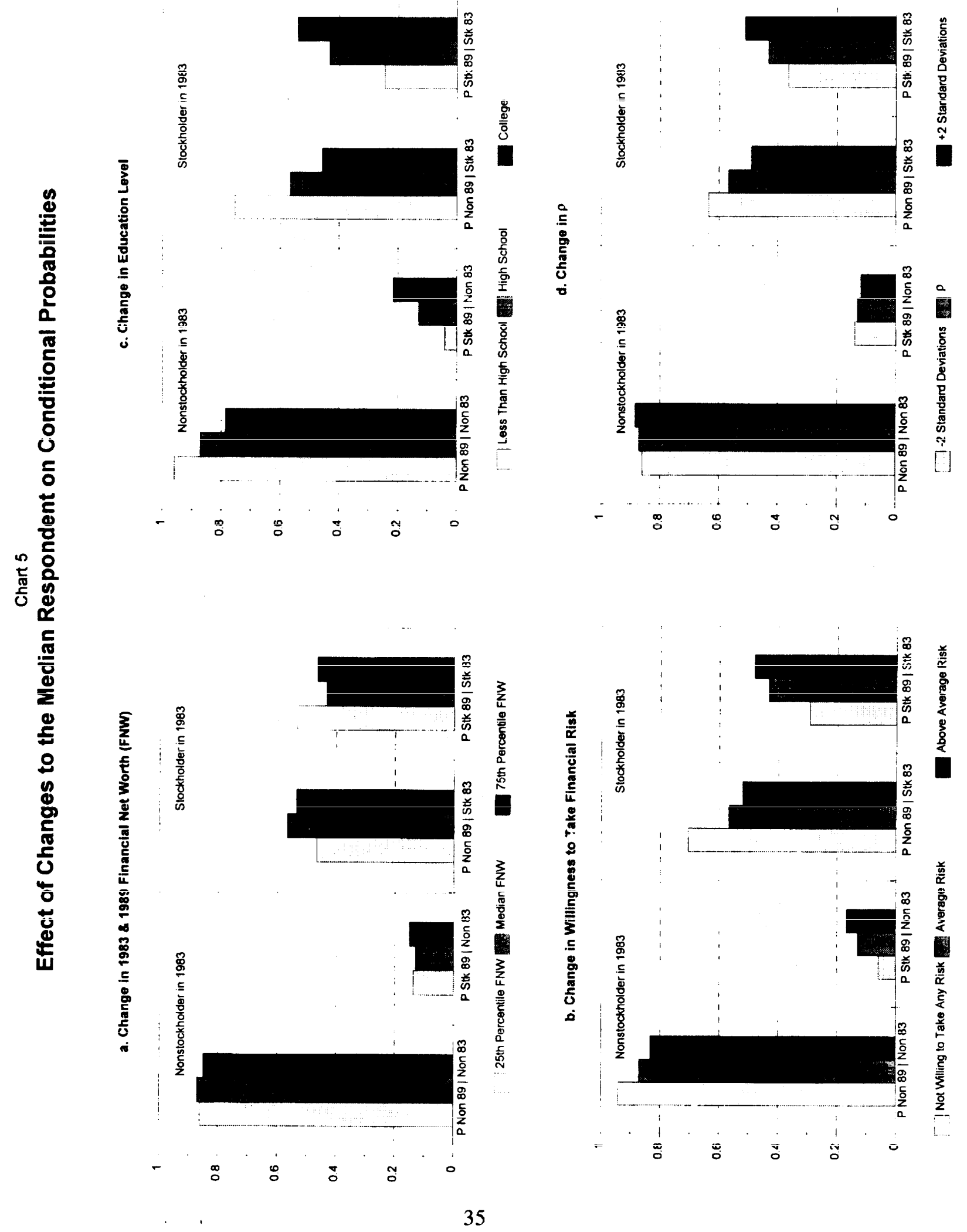




\section{Endnotes}

1. Data is for average real return on Standard and Poor's 500 Index and three month U.S. Treasury bills for 1889-1978 [Mehra and Prescott (1985)].

2. There is a growing body of literature addressing the "portfolio puzzles" of representative agent models such as the Consumption Capital Asset Pricing Model (CCAPM). Previous attention has addressed "return puzzles." The best known of these is perhaps the "equity premium puzzle" [Mehra and Prescott (1985), Abel (1991)]. Mankiw and Zeldes (1991) found that when CCAPM is applied only to U.S. stockholders, its performance is much improved. Haliassos and Bertaut (1995) provide theoretical and econometric analysis of why households abstain from the stock market. Poterba and Samwick (1995) document the extent of household stock ownership from the 1962, 1983, and 1992 Surveys of Consumer Finances, and investigate whether changing patterns of stock ownership have affected the relation between consumption and stock prices.

3.The puzzle of the low incidence of stockholding appears to be present in the Swedish data as well. Of the Swedish household sample used by Agell and Edin (1990), $75.2 \%$ held bank checking or savings accounts, while only $18.6 \%$ held common stocks.

4. Costs associated with stock investment can occur in two stages. First, there is the acquisition of information about the general risks and benefits of investing in the stock market. This can be through the purchase of investment guides, or through the time spent attending seminars on investment strategies, in identifying a good broker or financial advisor, or in conversations with relatives and colleagues. Once the decision to enter the market is made, there are additional ongoing costs of how to manage the portfolio. Fees paid to brokers or financial advisors become ongoing expenses, but are likely to be proportional to transactions.

5. Some households classified as nonstockholders in both 1983 and 1989 may be very active mâket participants, but happented to have liquidated their positions in both interview periods. Evidence from the 1983 Survey suggests that this is a rare occurrence. Only one household reported having a brokerage account and trading in the year previous to the interview, but not holding any stocks at the time of the interview.

6. As usually formulated, such a restriction limits the sum of the risky and riskless assets to be $\geq 0$, and does not rule out riskless borrowing for stock investment.

7. Because the average rate of interest on credit cards exceeds the Mehra-Prescott return on stocks, households in a standard CCAPM do not find it optimal to both borrow at the higher riskless rate and hold positive investments in stocks (Bertaut 1993).

8. An altemative investment rule of thumb is that the proportion of the portifolio in stocks should be 100 minus current age. Under this strategy, the investment horizon should not 
matter for the decision of whether or not to hold stocks, since all households should hold some fraction of the portfolio in stocks. Instead, reasons for non-participation would more likely reflect a perception of the costs and risks associated with stockholding relative to the perceived benefits.

9. The 1983-1989 SCF panel data set includes weights to derive population values.

10. For 1983, the median population response was "willing to take average financial risk." However, in 1989, the median was "not willing to take any financial risk," while "willing to take average risk" was recorded at the 53rd percentile. Because this change in willingness to take financial risk distorts probability distributions, the value "willing to take average risk" was used to represent the population median in 1989 as well.

11. For instance, 52 respondents held stocks in 1983 and 77 respondents held stocks in 1989 , although they claimed at the time that they were "not willing to take any financial risk." However, some of these risk averse stockholders could be describing actual portfolio decisions because they are unwilling to take on additional risk at the margin. Kennickell, Starr-McCluer, and Sunden (1996) find respondents in a small focus group of fairly sophisticated investors who held stocks but nonetheless declared themselves "not willing to take financial risk," meaning that they did not make uninformed ("risky") investment decisions.

12. Starr-McCluer (1995) investigates whether changes in household circumstances can explain changes in stated risk preference in the 1983-1989 SCF panel, and finds only limited evidence that even substantial changes in health, income, or marital status can explain changes in risk preference. Kimball and Shapiro (1995) also find changes in self-expressed risk tolerance in between waves I and II (taken two years apart) of the Health and Retirement Survey.

13. This variable may not be a pure measure of intentions, because the ability to leave a bequest may reflect the success of past investments which in turn may be a function of past stock market participation. Another variable (X5824) asks about the importance of leaving a bequest. Estimation with this variable instead produced an insignificant coefficient.

14. Using population-weighted estimates from the 1983-1989 SCF panel, Kennickell and Starr-McCluer (1996) find that a slightly larger percentage of households (9.9 percent) acquired securities (defined as stocks, bonds, and trusts and other managed accounts) between 1983 and 1989 than ceased holding securities between 1983 and 1989 (9 percent). The percentage of households owning securities generally increases with age. However, for households over 65 , the percentage that held securities in 1983 but not 1989 was considerably larger than the percentage acquiring such assets.

15. Under the null hypothesis of no correlation, the joint likelihood is simply the sum of the likelihoods from univariate probit regressions estimated for 1983 and 1989 separately. The sum of these likelihoods is -1026.168 . 
Replicate $=3:$ IF $(X !-X X ! * 10=3)$;

Respondent is same in 1983 and 1989: IF $(X 27206=1)$ OR $(X 27206=2)$ OR $(X 27206=13)$;

Resulting sample has 1,368 observations

1. Age Ranges (1989 age):

$\mathrm{X} 8022$

Age less than $35=$ omitted dummy

Age ranges: (X8022 GE 35) AND ( X8022 LT 45); ( X8022 GE 45) AND ( X8022 LT 55); ( X8022 GE 55) AND (X8022 LT 65); ( X8022 GE 65) AND ( X8022 LT 75); ( X8022 GE 75);

2. Sex:

$(X 8021=1):$ Male;

3. Race:

(X5909 = 5): White:

4. Education of household head:

(X5901 LT 12) AND (X5902 = 5): No high school diploma or equivalent:

$((X 5901$ LT 12) AND (X5902 = 1)) OR (X5901 = 12) OR ((X5901 GT 12) AND (X5904 = 5)): High school diploma or equivalent but no college degree:

(X5901 GT 12) AND (X5904 = 1): College degree (omitted dummy);

5. Married in 1983:

$((X 27207=1)$ OR $(X 27207=2)$ OR $(X 27207=3)$ OR $(X 27207=4)$ OR $(X 27207=5)$ OR $(X 27207=10)$ OR $(X 27207=11)$ OR $(X 27207=13)$ OR $(X 27207=15)$ OR $(X 27207=16)$ OR $(X 27207=17)$ : : Married or living with partner;

6. Managerial occupation:

1983: $(X 50221=2)$ OR $(X 50221=3)$ :

1989: $(X 7401=2)$ OR $(X 7401=3)$;

7. Low unemployment risk occupation: occupation has average unemployment rate more than one standard deviation below the mean unemployment rate (derived from Census Bureau data from 1970-1992), and the unemployment rate is significantly less variable. Low-risk occupations are professional, technical, and kindred; managers, adminsitrators, and self-employed managers; and sales, clerical, and kindred workers.

1983: $(X 50221=1)$ OR $(X 50221=4)$ OR $(X 50221=2)$ OR $(X 50221=3)$;

i989: $(\mathrm{X} 740 \mathrm{i}=\mathrm{i})$ OR $(\mathrm{X} 740 \mathrm{i}=4)$ OK $(\mathrm{X} 740 \hat{i}=2)$ OR $(\mathrm{X} 740 \hat{1}=3)$;

8. High unemployment risk occupation: occupation has average unemployment rate more than one standard deviation above the mean unemployment rate and the unemployment rate is significantly more variable. Highunemployment risk occupations are operatives, laborers, and kindred workers.

1983: $(X 50221=6)$ :

1989: $(X 7401=6)$;

9. Willingness to take financial risk:

1983: (X50203 = 1) OR (X50203 = 2): Take substantial risk for substantial return or take above average risk for above average return; $(X 50203=3)$ : Take average risk for average retum; $(X 50203=4)$ : Not willing to take any financial risk (omitted dummy); 
1989: $(X 3014=1)$ OR $(X 3014=2)$ : Take substantial risk for substantial return or take above average risk for above average return; $(X 3014=3)$ : Take average risk for average return; $(X 3014=4)$ : Not willing to take any financial risk (omitted dummy);

10. Household head retired in 1983:

$(\mathrm{X} 50220=50)$ OR $(\mathrm{X} 50220=51)$ OR $(\mathrm{X} 50220=52)$;

11. Ln(labor income): income from wages, salaries, professional practice or business, unemployment compensation, social security, annuity, or other pensions

1983 Labor income: X50261 + X50263 + X50275 + X50281; IF (LABINC83 GE 1) THEN LLINC83 = LOG(LABINC83); ELSE IF (LABINC83 GT -1) AND (LABINC83 LT 1) THEN LLINC83 = 0; ELSE IF (LABINC83 LE - 1) THEN LLINC83 = -(LOG(NEGINC83));

1989 Labor Income: X5702 + X5704 + X5716 + X5722; IF (LABINC89 GE 1) THEN LLINC89 = LOG(LABINC89); ELSE IF (LABINC89 GT -1) AND (LABINC89 LT 1) THEN LLINC89 = 0; ELSE IF (LABBINC89 LE -1) THEN LLIINC89 = -(LOG(NEGINC89)):

12. In (Financial net worth): Financial assets: dollar amount in checking, saving, money market accounts, CD, IRAs and Keoghs, shares in mutual funds, stocks, bonds, call money accounts, trust accounts, and cash value of life insurance; minus consumer debt: credit card balances, installment loans, home equity loans, and other revolving debt:

1983: FINAST83 $=$ X50002 +X50004 +X50006 +X50008 +X50010 +X50012+X50014 + X50016+X50018+ $X 50020+X 50022+X 50024+X 50026+X 50028+X 50030+X 50032+X 50034+X 50036$

CONDBT83 $=$ X50053 + X50055 + X50091 + X50094 + X50097+X50099;

FNTWTH83 = FINAST83 - CONDBT83; NEGFNW83 = - 1 *FNTWTH83; NEGINC83 = -1 *LABINC83; NEGNFW83 = - 1 *NONFNW83; IF (FNTWTH83 GE 1) THEN LFNW83 = LOG(FNTWTH83); ELSE IF (FNTWTH83 GT - 1) AND (FNTWTH83 LT 1) THEN LFNW83 = 0; ELSE IF (FNTWTH83 LE - 1) THEN LFNW83 $=-($ LOG $($ NEGFNW83) $)$;

1989 transactions accounts: checking+saving+money market $):$ LQ89 $=$ MAX $(0, X 3506)+M A X(0,3510)+$ $\operatorname{MAX}(0, X 3514)+\operatorname{MAX}(0 . X 3518)+\operatorname{MAX}(0, X 3522)+\operatorname{MAX}(0, X 3526)+\operatorname{MAX}(0, X 3529)+\operatorname{MAX}(0, X 3706)+$ $\operatorname{MAX}(0, X 3711)+\operatorname{MAX}(0, X 3716)+\operatorname{MAX}(0, X 3718)+\operatorname{MAX}(0, X 3804+X 3807+X 3810+X 3813+X 3816+$ $\mathrm{X} 3818)+\operatorname{MAX}(0, X 3930) ; \operatorname{CHECK} 89=\operatorname{MAX}(0, X 3506)+\operatorname{MAX}(0, X 3510)+\operatorname{MAX}(0, X 3514)+\operatorname{MAX}(0, X 3518)+$ MÁX̄ $(\hat{0}, \bar{X} 35 \overline{2} 2)+\operatorname{MAX}(0, X 3526)$;

1989 certificates of deposit: $\operatorname{CDS} 89=\mathrm{X} 3721$;

1989 directly held stock: STOCKS89 = X3915;

1989 total quasi-liquid retirement accounts (IRAs + thrift/saving type pensions, 401k's, types that can be borrowed against or from which can make withdrawal: IRAS89 $=\operatorname{MAX}(0, X 3610)+\operatorname{MAX}(0, X 3620)+\operatorname{MAX}(0, X 3630)$; 1989 quasi-liquid retirement assets: IF $((X 4216=1)$ OR $(X 4216=2))$ AND $((X 4227=1)$ OR $(X 4231=1))$ THEN RET1 $89=$ MÁX $(0, X 4226)$; İF $(X 4316=1)$ OR $(X 4316=2)$ AND $((X 4327=1)$ OR $(X 4331=1))$ THEN RET289= $\operatorname{MAX}(0, X 4326) ; \operatorname{IF}(X 4416=1)$ OR $(X 4416=2)$ AND $((X 4427=1)$ OR $(X 4431=1))$ THEN RET389= $\operatorname{MAX}(0, X 4426)$; IF $(X 4816=1)$ OR $(X 4816=2)$ AND $((X 4827=1)$ OR $(X 4831=1))$ THEN RET489= MAX $(0, X 4826)$; IF $(X 4916=1)$ OR $(X 4916=2)$ AND $((X 4927=1)$ OR $(X 4931=1)$ ) THEN RET589= $\operatorname{MAX}(0, X 4926) ; \operatorname{IF}(X 5016=1)$ OR $(X 5016=2)$ AND $((X 5027=1)$ OR $(X 5031=1))$ THEN RET689= $\operatorname{MAX}(0, X 6026)$;

RET89 = RET189 + RET289 + RET389 + RET489 + RET589 + RET689; RETQLQ89 = RET89 + IRAS89; 1989 directly held mutual funds: NMMF89 $=\operatorname{MAX}(0, X 3822)+\operatorname{MAX}(0, X 3824)+\operatorname{MAX}(0, X 3826)+$ $\operatorname{MAX}(0, X 3828)+\operatorname{MAX}(0, X 3830) ;$

1989 directly held bonds: BOND89 $=$ X3910 + X3906 + X3908 + X3912;

1989 managed assets (trusts, annuities, managed investment accounts): OTHMA89 = X3942;

1989 cash value of whole life insurance: CASHLI89 = MAX $(0, X 4006)$;

1989 savings bonds: SAVBND89 = X3902;

1989 other financial assets: OTHFIN89 $=X 4018+X 4022 *((61<=X 4020<=66)$ OR $(72<=X 4020<=74))+$ $X 4026 *((61<=X 4024<=66)$ OR $(72<=X 4024<=74))+X 4030 *((61<=X 4028<=66)$ OR $(72<=X 4028<=74))$; 1989 total financial assets: FINAST89 = LIQ89 + CDS89 + RETQLQ89 + STOCKS89 + BOND89 + NMMF89 + OTHMA89 + CASHLI89 + SAVBND89 + OTHFIN89; 
1989 consumer loans and credit card debts: $C C B A L 89=\operatorname{MAX}(0, X 427)+\operatorname{MAX}(0, X 413)+\operatorname{MAX}(0, X 421)+$ $\operatorname{MAX}(0, X 430)+\operatorname{MAX}(0, X 424)+\operatorname{MAX}(0, X 7575) ;$ INSTAL89 $=X 2218+X 2318+X 2418+X 2424+X 2519+$ $X 2619+X 2625+X 2723^{*}\left(X 2710^{\wedge}=67\right)+X 2740^{*}\left(X 2727^{\wedge}=67\right)+X 2823^{*}\left(X 2810^{\wedge}=67\right)+X 2840^{*}\left(X 2827^{\wedge}=67\right)+$ $\mathrm{X} 2923 *\left(\mathrm{X} 2910^{\wedge}=67\right)+\mathrm{X} 1044+\mathrm{X} 1215+\mathrm{X} 1219 ; \mathrm{HELOC} 89=\mathrm{X} 1108+\mathrm{X} 1119+\mathrm{X} 1130$;

1989 other debts (loans against retirement accounts, cash value life insurance, margin accounts. other debts): OTHDBT89 = X4229 + X4329 + X4429 + X4829+X4929+X5029+X4010+X4032 + MAX(0,X3932); CONDBT89 = CCBAL89 + INSTAL89 + HELOC89 + OTHDBT89;

FNTWTH89 = FINAST89 - CONDBT89;

IF (FNTWTH89 GE 1) THEN LFNW89 = LOG(FNTWTH89); ELSE IF (FNTWTH89 GT -1) AND (FNTWTH89 LT 1) THEN LFNW89 = 0; ELSE IF (FNTWTH89 LE -1) THEN LFNW89 = -(LOG(NEGFNW89));

13. In (nonfinancial net worth): value of home net of mortgages outstanding, other real estate net of loans outstanding, business net of loans outstanding, and vehicles net of loans outstanding, 1983: NONFNW83 = X50064 - X50069 + X50072 - X50073 + X50075 - X50076 - X50086 + X50089 - X50091 + $\bar{X} 50080+\bar{X} 500 \overline{8} 2$

IF (NONFNW83 GE 1) THEN LNFNW83 = LOG(NONFNW83); ELSE IF (NONFNW83 GT -1) AND (NONFNW83 LT 1) THEN LNFNW83 = 0; ELSE IF (NONFNW83 LE -1) THEN LNFNW83 = -(LOG(NEGNFW83)); 1989: NONFNW89 $=\mathrm{X} 604+\mathrm{X} 614+\mathrm{X} 623+\mathrm{X} 716-\mathrm{X} 805-\mathrm{X} 905-\mathrm{X} 1005+(\mathrm{X} 1705 / 10000) *(\mathrm{X} 1706-\mathrm{X} 1715)+$ $(X 1805 / 10000) *(X 1806-X 1815)+(X 1905 / 10000) *(X 1906-X 1915)+X 2002-X 2006+X 2012-X 2015$ $+\mathrm{X} 2422+\mathrm{X} 2506+\mathrm{X} 2606+\mathrm{X} 2623+\mathrm{X} 3129-\mathrm{X} 3126+\mathrm{X} 3229-\mathrm{X} 3226+\mathrm{X} 3329-\mathrm{X} 3326+\mathrm{X} 3335+\mathrm{X} 3408+$ $\mathrm{X} 3412+\mathrm{X} 3416+\mathrm{X} 3420+\mathrm{X} 3428$

IF (NONFNW89 GE 1) THEN LNFNW89 = LOG(NONFNW89); ELSE IF (NONFNW89 GT -1) AND (NONFNW89 LT 1) THEN LNFNW89 = 0; ELSE IF (NONFNW89 LE -1) THEN LNFNW89 = -(LOG(NEGNFW89));

14. Always pay off credit card balances

1983: $(\mathrm{X} 50051=1)$;

1989: $(\mathrm{X} 432=1)$ :

15. Credit constrained: household was turned down for credit (and did not eventually receive amount initially requested), did not receive as much credit as requested, or did not apply for credit because thought they might be turned down.

1983: $(((X 50046=1)$ OR $(X 50046=3))$ AND (X50047 NE 1)) OR $(X 50048=1)$;

1989: $(((X 407=1)$ OR $(X 407=3))$ AND $(X 408$ NE 1)) OR $(X 409=1)$;

16. Inherited wealth:

1983: $(X 50215=2)$ OR (X50215 = 3): Inherited majority of wealth;

1989: $(X 5801=1)$ : Received substantial inheritance;

17. Intend to leave bequest (1989):

$(\mathrm{X} 5825=1)$;

18. Willingness to tie up funds/long term planning horizon

1983: (X50204 = 1) OR (X50204 = 2): willing to tie up funds to achieve above average retum;

1989: $(X 3008=4)$ OR (X3008 = 5): main financial planning horizon is five or more years;

Change to marital status:

20. Married to same spouse in 1989

IF (MARRY83 = 1) AND (MARRY89 = 1) AND (GETMARRY = 0) THEN SAMEMARY = 1;

21. Became married between $1983-1989$ (even if married in 1983):

$((X 27207=3)$ OR $(X 27207=4)$ OR $(X 27207=5)$ OR $(X 27207=6)$ OR $(X 27207=7)$ OR $(X 27207=8)$ OR $(X 27207=9)$ OR $(X 27207=15)$ OR $(X 27207=16)$;

22. Divorced/widowed/separated in 1989

$((X 27207=10)$ OR $(X 27207=11)$ OR $(X 27207=13)$ OR $(X 27207=17))$;

Omitted dummy: remain single in 1989 
Change to employment status:

23. Lost main job between 1983-1989

$((\mathrm{X} 24517=2)$ OR $(\mathrm{X} 24517=3)$ OR $(\mathrm{X} 24517=4)$ OR $(\mathrm{X} 24517=5)$ OR $(\mathrm{X} 24517=6)$ OR $(\mathrm{X} 24517=-7)$ OR $(X 25117=2)$ OR $(X 25117=3)$ OR $(X 25117=4)$ OR $(X 25117=5)$ OR $(X 25117=6)$ OR $(X 24517=-7))$;

24. New main job between 1983-1989:

$((X 24515=1)$ AND $(X 24516=2))$ OR $((X 25115=1)$ AND $(X 25116=2))$ OR $((X 24515=5)$ AND $((X 4106=1)$

OR $(\mathrm{X} 4106=2)))$ OR $((\mathrm{X} 25115=5)$ AND $((\mathrm{X} 4706=1)$ OR $(\mathrm{X} 4706=2)))$;

25. Became retired between 1983-89

$(\mathrm{X} 4100=50)$;

26. Remain retired in $\mathbf{1 9 8 9}$

IF (RETIRE83 = 1) AND (RETIRE89 = 1) AND (RETIRED = 0);

Omitted dummy: no change to main job

27. In(actual expense on education 1983-89)

IF $(X 26216>1)$ THEN PAYED = LOG $(X 26216)$;

28. Bought house between 1983-89

IF $(\mathrm{X} 26002=1)$ OR $(\mathrm{X} 26002=3)$ THEN BUYHSE = 1 ;

30. Stockholding status:

publicly traded stocks + stocks in investment clubs + other publicly traded stocks + shares in mutual funds; minus stocks in company in which respondent (or household member) employed;

1983: STKXC83 = X50026 + X50014 +X50016;

IF $($ STKXC83 > 0) THEN STKXO83 = 1;

1989: $\quad$ STKXC89 $=$ X3915 + MAX $(0, X 3822)+(.5)^{*}(\operatorname{MAX}(0, X 3830))-X 3922$;

IF (STKXC89 > 0) THEN STKXO89 = 1;

IF $($ STKXO83 = 0) AND (STKXO89 = 0) THEN STK8389 = ;

ELSE IF (STKXO83 = 1) AND (STKXO89 = 0) THEN STK8389 = 2;

ELSE IF (STKXO83 = 0) AND (STKXO89 = 1) THEN STK8389 = 3;

ELSE IF (STKXO83 = 1) AND (STKXO89 = 1) THEN STK8389 = 4; 


\section{International Finance Discussion Papers}

IFDP

Number

Stockholding Behavior of U.S. Households: Evidence from the 1983-89 Survey of Consumer Finances

557 Firm Size and the Impact of Profit-Margin Uncertainty on Investment: Do Financing Constraints Play a Role?

556 Regulation and the Cost of Capital in Japan: A Case Study

555 The Sovereignty Option: The Quebec Referendum and Market Views on the Canadian Dollar

$554 \quad$ Real Exchange Rates and Inflation in Exchange-Rate Based Stabilizations: An Empirical Examination

553 Macroeconomic State Variables as Determinants of Asset Price Covariances

552 The Tequila Effect: Theory and Evidence from Argentina

551 The Accumulation of Human Capital: Alternative Methods and Why They Matter

550 Alternatives in Human Capital Accumulation: Implications for Economic Growth

549 More Evidence on the Link between Bank Health and Investment in Japan

$548 \quad$ The Syndrome of Exchange-Rate-Based Stabilization and the Uncertain Duration of Currency Pegs

547 German Unification: What Have We Learned from Multi-Country Models?

Returns to Scale in U.S. Production: Estimates and Implications

Author(s)

Carol C. Bertaut

Vivek Ghosal

Prakash Loungani

John Ammer

Michael S. Gibson

Michael P. Leahy

Charles P. Thomas

Steven B. Kamin

John Ammer

Martín Uribe

Murat F. Iyigun

Ann L. Owen

Murat F. lyigun

Ann L. Owen

Michael S. Gibson

Enrique G. Mendoza

Martin Uribe

Joseph E. Gagnon

Paul R. Masson

Warwick J. McKibbin

Susanto Basu

John G. Fernald

Please address requests for copies to International Finance Discussion Papers, Division of International Finance, Stop 24, Board of Governors of the Federal Reserve System, Washington, DC 20551. 


\section{International Finance Discussion Papers}

IFDP

Number

$\underline{\text { Titles }}$

Author(s)

$\underline{1996}$

545 Mexico's Balance-of-Payments Crisis: A Chronicle of Death Foretold

544 The Twin Crises: The Causes of Banking and Balance-of-Payments Problems

$543 \quad$ High Real Interest Rates in the Aftermath of Disinflation: Is it a Lack of Credibility?

542 Precautionary Portfolio Behavior from a Life-Cycle Perspective

$541 \quad$ Using Options Prices to Infer PDF's for Asset Prices: An Application to Oil Prices During the Gulf Crisis

540 Monetary Policy in the End-Game to Exchange-Rate Based Stabilizations: The Case of Mexico

539 Comparing the Welfare Costs and the Initial Dynamics of Alternative Temporary Stabilization Policies

538 Long Memory in Inflation Expectations: Evidence from International Financial Markets

Using Measures of Expectations to Identify the Effects of a Monetary Policy Shock

\section{Regime Switching in the Dynamic Relationship} between the Federal Funds Rate and Innovations in Nonborrowed Reserves

The Risks and Implications of External Financial

Shocks: Lessons from Mexico

Currency Crashes in Emerging Markets: An

Empirical Treatment

Regional Pattems in the Law of One Price:

The Roles of Geography vs. Currencies

$\underline{1995}$

532
Âggregate Productivity and the Productivity of Aggregates
Guillermo A. Calvo

Enrique G. Mendoza

Graciela L. Kaminsky

Carmen M. Reinhart

Graciela L. Kaminsky

Leonardo Leiderman

Carol C. Bertaut

Michael Haliassos

William R. Melick

Charles P. Thomas

Steven B. Kamin

John H. Rogers

Martin Uribe

Joseph E. Gagnon

Allan D. Brunner

Chan Huh

Edwin M. Truman

Jeffrey A. Frankel

Andrew K. Rose

Charles Engel

John H. Rogers

Susanto Basu

John G. Fernald 